\title{
Electrically Induced Opening of Composite PLA/SWCNT Microchambers for Implantable Drug Depot Systems
}

\author{
A. V. Ermakov, E. V. Lengert, M. S. Saveleva, G. B. Sukhorukov
}

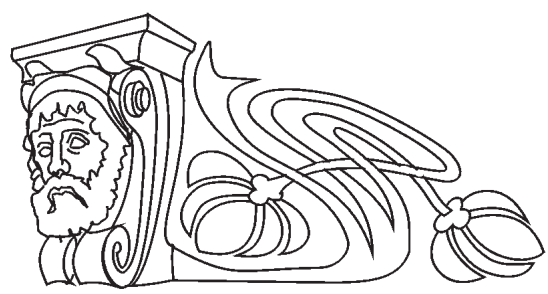

Alexey V. Ermakov, https://orcid.org/0000-0001-8105-5932, I. M. Sechenov First Moscow State Medical University, 2 Bol'shaya Pirogovskaya St., Moscow 119991, Russia, ermakov.ssu@gmail.com

Ekaterina V. Lengert, https://orcid.org/0000-0002-6447-2811, Saratov State University, 83 Astrakhanskaya St., 410012 Saratov, Russia; Saratov State Medical University named after V. I. Razumovsky, 112 Bolshaya Kazachya St., 410012 Saratov, Russia, lengertkatrin@ mail.ru

Mariia S. Saveleva, https://orcid.org/0000-0003-2021-0462, Saratov State University, 83 Astrakhanskaya St., 410012 Saratov, Russia; Saratov State Medical University named after V. I. Razumovsky, 112 Bolshaya Kazachya St., 410012 Saratov, Russia, mssaveleva@ yandex.ru

Gleb B. Sukhorukov, https://orcid.org/0000-0001-6213-0562, Queen Mary University of London, Mile End Road, London E1 4NS, UK, g.sukhorukov@qmul.ac.uk

Time- and site-specific release of bioactive compounds mediated by microcontainers immobilized on a surface is of high importance in a variety of tasks related to biomedicine and functional coatings. In the present work, we investigate arrays of hollow microchambers formed by composite shells based on a polylactic acid matrix and single-walled carbon nanotubes filler with high responsiveness towards electric current stimuli. The monitoring of the morphology changes reveals significant damages to the shells of microchambers formed by conductive composite material. The voltage of $3 \mathrm{~V}$ is shown to be sufficient to induce thermal damages to the microchambers. This study demonstrates the in-principle possibility to realize the opening of polylactic acid-based microchambers by application of low-power currents. The developed system opens a promising avenue for implantable delivery routes in a number of areas related to smart coatings, time and site-specific release. We believe these results will find application in the development of new implantable drug depot systems in biomedicine and cosmetology.

Keywords: microchambers, composite material, polylactic acid, carbon nanotubes.

Received: 22.09.2020 / Accepted: 13.10.2020 / Published: 30.11.2020

This is an open access article distributed under the terms of Creative Commons Attribution License (CC-BY 4.0)

DOI: https://doi.org/10.18500/1817-3020-2020-20-4-311-314

\section{Introduction}

Surface-mediated system for storage and activated release of bioactive substances are of interest in a variety of applications ranging from self-disinfecting surfaces to tissue regenerative medicine [1-3]. Discovered recently microchambers $[4,5]$ opens new horizons in these terms due to high encapsulation ability, flexible selection of materials depending on the task which makes it possible to tune the properties of the chambers with high accuracy. Recently, microchamber's arrays were shown to store lowmolecular-weight cargo [6] for a significant time scale and release it in response to a range of external stimuli such as ultrasound [7], NIR light [8], and enzymatic treatment [9]. Devices based on similar functions were widely applied as implantable drug delivery systems [10-12]. Biodegradable microchambers implanted to white rats were shown to provide prolonged release of the model drug in vivo $[13,14]$. However, in some cases, the burst release of encapsulated cargo is more effective [15]. In this regard, biocompatible stimuli and readily available stimuli for controlled release are of high demand. Here, we investigate a polylactic-based array of microchambers functionalized with single-walled carbon nanotubes to induce the thermal opening of microchambers provided by the application of the low voltages.

\section{Experimental section}

\subsection{Materials}

Polylactic acid ( $3 \mathrm{~mm}$ granule, $M_{\mathrm{w}} \sim 60 \mathrm{kDa}$ ) (PLA) and chloroform (99.5\%) were purchased from Sigma-Aldrich and used as received. The poly(dimethylsiloxane) (PDMS) kit, consisting of a prepolymer and a curing agent (Sylgard 184), was purchased from Dow-Corning, Midland, USA.

\subsection{Microchambers fabrication}

Fabricate of PLA microchambers was made through patterned PDMS templates. Prepolymer-curing agent (10:1) mixture was used to make a replica from the silicon master mold. Silicon master mold containing 850000 micro-pillars was immersed in the prepolymer-curing agent mixture followed by a degasation procedure. Then PDMS was solidified at $80^{\circ} \mathrm{C}$ for $1 \mathrm{~h}$. The silicon masters were prepared by traditional photolithography and had round micropillars with a side of $12 \mu \mathrm{m}$, the height of $10 \mu \mathrm{m}$, and center-to-center distance of $16 \mu \mathrm{m}$. The PLA microchambers were prepared in two steps: first, the patterned PDMS template was covered with a thin layer of PLA and in the second step it was transferred 
to a counter substrate covered with a thin layer of PLA as well. After transferring, the PDMS template was mechanically removed resulting in an array of hollow microchambers on top of the counter substrate. More details on the fabrication of microchambers can be found in of our recent papers [6].

\subsection{Characterization techniques}

Cyclic voltammetry and application of the potential difference to the surface of microchambers were provided using Agilent probe station PM5 equipped with four probes. Scanning electron microscopy (SEM) images were obtained using a Tescan MIRA II LMU setup (Tescan, Czech Republic).

\section{Results and discussion}

In this work, two types of hollow microchambers with a size of $10 \mu \mathrm{m}$ and a total area of the array of $1 \mathrm{~cm}^{2}$ were fabricated. PLA was selected as a polymer matrix to form shells of the microchambers. To functionalize microchambers with a range of superior properties, PLA was blended with the suspension of SWCNT. In this regard, chloroform-based suspension of SWCNT with the length of $2.2 \mu \mathrm{m}$ mixed with $1 \%$ solution of PLA in chloroform was used to prepare composite shells of microchambers with the total content of SWCNT of 0.01 mass $\%$. SWCNT are widely applied as a filler of composite materials due to a unique combination of excellent properties such as optical, mechanical, and electrical. SEM images demonstrated the successful formation of the microchambers hollow structure for both compositions with no significant changes in morphology caused by the presence of SWCNT in the structure.

The electrical conductivity of the composite microchambers was estimated via 4 probe technique. PLA composition was found to be dielectric, while SWCNT-based composite exhibit increased conductivity up to $5 \pm 2 \mathrm{~S} \cdot \mathrm{cm}^{-1}$, which indicate the dense distribution of SWCNT over the film. This value is comparable to the highest values of the conductivity for polymer-based composites described in the literature.

Such a high conductivity of the film opens a value for the opening of the chambers by thermal treatment induced by Joule heating according to the following equation:

$$
Q=I \cdot U \cdot \Delta t
$$

The opening of the chambers was carried out as follows: two probes were placed to the surface of the array at the distance of 25-30 $\mu \mathrm{m}$ from each other followed by the application of potential difference of 1-3 V between them for $1 \mathrm{~s}$. The scheme of the experiment is shown in Figure 1.

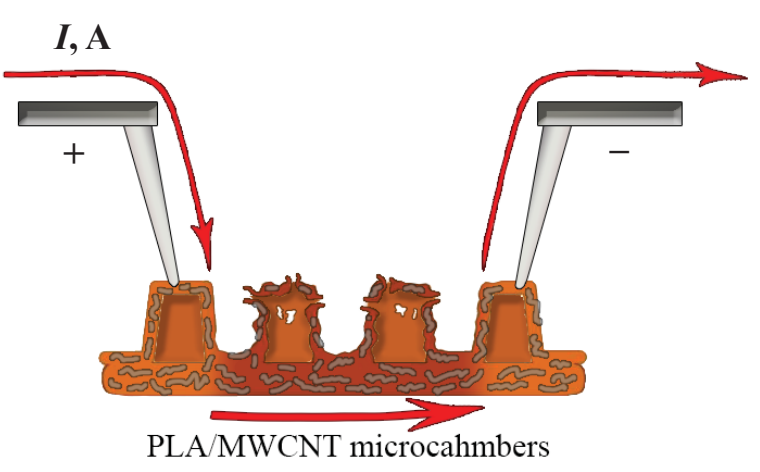

Fig. 1. Schematic picture of the experimental setup

It should be noted that PLA is a quite refractory material with a melting point of 180 degrees which makes the microchamber's array stable in a wide range of the temperatures. In this regard, the local temperature on the surface of the array between electrical probes must be above $180^{\circ} \mathrm{C}$ to induce the opening of microchambers. Microchambers formed by pure PLA film served as a control sample and potential difference up to $60 \mathrm{~V}$ between the probes has not been found to produce any damages in this case. SEM images were used to evaluate the morphology of the chambers before and after the application of the voltage (Fig. 2). Figure $2 a$ shows the morphology of the control microchamber array after application of the voltage of $60 \mathrm{~V}$. SEM image reveals no changes occur. Traces of cuts on the chambers evidence the electrodes placed over the surface. SEM images (Fig. $2 b, c$ ) show the morphology of the chambers after application of the voltage of $3 \mathrm{~V}$ which led to the electrical current between the probes of $60 \mu \mathrm{A}$. It can be seen that the morphology of the chambers between the probes loses its integrity due to the thermal effect caused by the electrical current.

These results show in-principal possibility to use the functionalization of microchambers by SWCNT to make them sensitive to the electric stimuli of the low voltage, which can be employed for the remote-controlled release of the encapsulated substance. Since the level of the electric current required for opening of microchambers are safe for humans, and PLA and nanotubes are widely used in biomedical problems, it seems that this array of chambers with a similar structure will find application as a drug depot system.

\section{Conclusions}

In this study, composite hollow microchambers with the shells composed of PLA matrix and SWCNT filler were successfully fabricated. PLA functionalized by SWCNT was found to be highly conductive material in contrast to pure PLA. The increased 

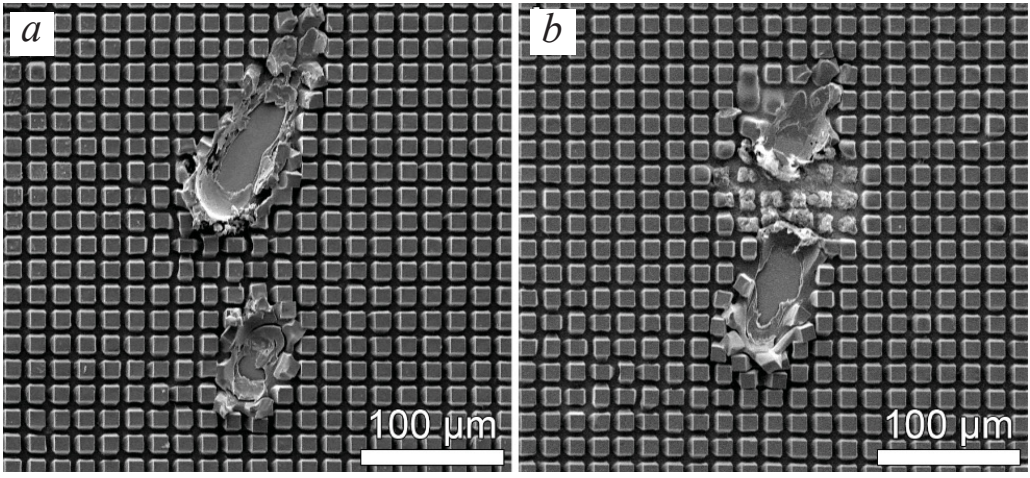

Fig. 2. SEM images of microchambers arrays after application of voltage: $a$ microchambers; $c$ - magnified image

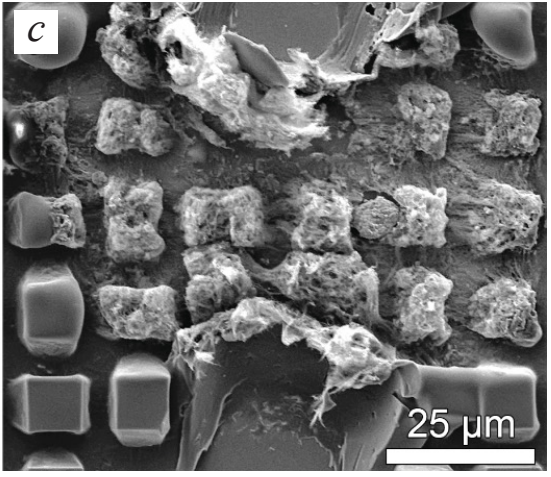

PLA microchambers; $b$ - PLA-SWCNT

conductivity of the material enabled Joule heating of the material leading to significant damages of the microchamber's shells. SEM images revealed intense damages of the microchamber's shells after application of the voltage of $3 \mathrm{~V}$ in contrast to the pure PLA sample which was stable under voltage of $60 \mathrm{~V}$. We have demonstrated the in-principle possibility to induce the opening of PLA-based microchambers with high responsiveness towards electric current stimuli by Joule heating. The developed system opens a promising avenue for implantable delivery routes in a number of areas related to smart coatings time and site-specific release. We believe these results will find application in the development of new implantable drug depot systems in biomedicine and cosmetology.

Acknowledgements: This work was supported by the Ministry of Science and Higher Education of the Russian Federation in the framework of the state task (project No. FSRR-2020-0002).

\section{References}

1. Daly A. C., Kelly D. J. Biofabrication of spatially organised tissues by directing the growth of cellular spheroids within 3D printed polymeric microchambers. Biomaterials, 2019, vol. 197, pp. 194-206.

2. Querido M. M., Aguiar L., Neves P., Pereira C. C., Teixeira J. P. Self-disinfecting surfaces and infection control. Colloids Surfaces B Biointerfaces, 2019, vol. 178, pp. 8-21.

3. Shah N. J., Hyder M. N., Moskowitz J. S., Quadir M. A., Morton S. W., Seeherman H. J., Padera R. F., Spector M., Hammond P. T. Surface-Mediated Bone Tissue Morphogenesis from Tunable Nanolayered Implant Coatings. Sci. Transl. Med., 2013, vol. 5, pp. 191ra83-191ra83.

4. Kiryukhin M. V., Gorelik S. R., Man S. M., Subramanian G. S., Antipina M. N., Low H. Y., Sukhorukov G. B. Individually addressable patterned multilayer microchambers for site-specific release-on-demand. Macromol. Rapid Commun., 2013, vol. 34, pp. 87-93.
5. Kiryukhin M. V., Lau H. H., Lim S. H., Salgado G., Fan C., Ng Y. Z., Leavesley D. I., Upton Z. Arrays of Biocompatible and Mechanically Robust Microchambers Made of Protein-Polyphenol-Clay Multilayer Films. ACS Biomater. Sci. Eng., 2020, pp. acsbiomaterials.0c00973.

6. Ermakov A. V., Kudryavtseva V. L., Demina P., Verkhovskii R., Zhang J., Lengert E., Sapelkin A., Goryacheva I. Y., Sukhorukov G. Site-specific release of reactive oxygen species from ordered arrays of microchambers based on polylactic acid and carbon nanodots. J. Mater. Chem. B, 2020, vol. 8, pp. 7977-7986.

7. Gai M., Frueh J., Tao T., Petrov A. V., Petrov V. V., Shesterikov E. V., Tverdokhlebov S. I., Sukhorukov G. B. Polylactic acid nano- and microchamber arrays for encapsulation of small hydrophilic molecules featuring drug release via high intensity focused ultrasound. Nanoscale, 2017, vol. 9, pp. 7063-7070.

8. Ermakov A., Lim S. H., Gorelik S., Kauling A. P., de Oliveira R. V. B., Castro Neto A. H., Glukhovskoy E., Gorin D. A., Sukhorukov G. B., Kiryukhin M. V. Polyelectrolyte-Graphene Oxide Multilayer Composites for Array of Microchambers which are Mechanically Robust and Responsive to NIR Light. Macromol. Rapid Commun., 2019, vol. 40, pp. 1700868.

9. Zhang J., Sun R., DeSouza-Edwards A. O., Frueh J., Sukhorukov G. B. Microchamber arrays made of biodegradable polymers for enzymatic release of small hydrophilic cargos. Soft Matter, 2020, vol. 16, pp. 2266-2275.

10. Khan A. N., Ermakov A., Sukhorukov G., Hao Y. Radio frequency controlled wireless drug delivery devices. Appl. Phys. Rev., 2019, vol. 6, pp. 041301.

11. Talebian S., Foroughi J., Wade S. J., Vine K. L., Dolatshahi-Pirouz A., Mehrali M., Conde J., Wallace G. G. Biopolymers for Antitumor Implantable Drug Delivery Systems: Recent Advances and Future Outlook. Adv. Mater., 2018, vol. 30, pp. 1706665.

12. Ermakov A. V., Lengert E. V., Venig S. B. Nanomedicine and Drug Delivery Strategies for Theranostics Applications. Izv. Saratov Univ. (N. S.), Ser. Physics, 2020, vol. 20, iss. 2, pp. 116-124. DOI: https://doi.org/10.18500/18173020-2020-20-2-116-124

13. Sindeeva O. A., Gusliakova O. I., Inozemtseva O. A., Abdurashitov A. S., Brodovskaya E. P., Gai M., 
Tuchin V. V., Gorin D. A., Sukhorukov G. B. Effect of a Controlled Release of Epinephrine Hydrochloride from PLGA Microchamber Array: In Vivo Studies. ACS Appl. Mater. Interfaces, 2018, vol. 10, pp. 37855-37864.

14. Maulvi F. A., Lakdawala D. H., Shaikh A. A., Desai A. R., Choksi H. H., Vaidya R. J., Ranch K. M., Koli A. R., Vyas B. A., Shah D. O. In vitro and in vivo evaluation of novel implantation technology in hydrogel contact lenses for controlled drug delivery. J. Control. Release, 2016, vol. 226, pp. 47-56.

15. Rodrigues de Azevedo C., von Stosch M., Costa M. S., Ramos A. M., Cardoso M. M., Danhier F., Préat V., Oliveira R. Modeling of the burst release from PLGA micro- and nanoparticles as function of physicochemical parameters and formulation characteristics. Int. J. Pharm., 2017, vol. 532, pp. 229-240.

\section{Cite this article as:}

Ermakov A. V., Lengert E. V., Saveleva M. S., Sukhorukov G. B. Electrically Induced Opening of Composite PLA/SWCNT Microchambers for Implantable Drug Depot Systems. Izv. Saratov Univ. (N. S.), Ser. Physics, 2020, vol. 20, iss. 4, pp. 311-314 (in Russian). DOI: https://doi.org/10.18500/1817-3020-2020-20-4-311-314

\section{УДК 53}

Вскрытие композитных микроконтейнеров из полимолочной кислоты и углеродных нанотрубок посредством электрического тока для имплантируемых лекарственных форм

\section{А. В. Ермаков, Е. В. Ленгерт, М. С. Савельева, Г. Б. Сухоруков}

Ермаков Алексей Вадимович, младший научный сотрудник, Первый Московский государственный медицинский университет имени И. М. Сеченова, ermakov.ssu@gmail.com

Ленгерт Екатерина Владимировна, младший научный сотрудник, Саратовский национальный исследовательский государственный университет имени Н. Г. Чернышевского; Саратовский государственный медицинский университет имени В. И. Разумовского, lengertkatrin@mail.ru

Савельева Мария Сергеевна, младший научный сотрудник, Саратовский национальный исследовательский государственный университет имени Н. Г. Чернышевского; Саратовский государственный медицинский университет имени В. И. Разумовского, mssaveleva@yandex.ru

Сухоруков Глеб Борисович, кандидат физико-математических наук, профессор, Университет Королевы Марии (Лондон, Великобритания), g.sukhorukov@qmul.ac.uk

Высвобождение биологически активных соединений в точно заданный момент времени и в требуемом участке посредством микроконтейнеров, иммобилизованных на поверхности, имеет большое значение для множества задач, связанных с биоме- дициной и функциональными покрытиями. В настоящей работе были исследованы массивы полых микрокамер, образованных композитными оболочками на основе матрицы из полимолочной кислоты и наполнителя из однослойных углеродных нанотрубок с высокой чувствительностью к воздействию электрическим током. Мониторинг морфологических изменений позволил установить значительные повреждения оболочек микрокамер, образованных проводящим композитным материалом. Показано, что напряжение 3 В достаточно для теплового повреждения микрокамер. Данное исследование демонстрирует принципиальную возможность реализовать вскрытие микрокамер на основе полимолочной кислоты за счет применения токов малой мощности. Разработанная система открывает многообещающие возможности для имплантируемых систем доставки в ряде областей, связанных с умными покрытиями и высвобождением вещества на конкретном участке в заданный момент времени. Мы полагаем, что данные результаты найдут применение при разработке новых имплантируемых лекарственных форм в биомедицине и косметологии.

Ключевые слова: микроконтейнеры, композитный материал, полимолочная кислота, углеродные нанотрубки.

Поступила в редакцию: 22.09.2020 / Принята: 13.10.2020 /

Опубликована: 30.11 .2020

Статья опубликована на условиях лицензии Creative Commons Attribution License (CC-BY 4.0)

\section{Благодарности}

Работа выполнена при финансовой поддержке Министерства науки и высшего образования Российской Федерации в рамках государственного задания (проект № ФСРР-2020-0002).

\section{Образец для цитирования:}

Ermakov A. V., Lengert E. V., Saveleva M. S., Sukhorukov G. B. Electrically Induced Opening of Composite PLA/SWCNT Microchambers for Implantable Drug Depot Systems [Ермаков А. В., Ленгерт Е. В., Савельева М. С., Сухоруков Г. Б. Вскрытие композитных микроконтейнеров из полимолочной кислоты и углеродных нанотрубок посредством электрического тока для имплантируемых лекарственных форм] // Изв. Сарат. ун-та. Нов. сер. Сер. Физика. 2020. T. 20, вып. 4. C. 311-314. DOI: https://doi.org/10.18500/1817-3020-2020-20-4-311-314 